\title{
The Choreography of Talent Development in Higher Education
}

\author{
Fahdia Khalid ${ }^{1,2}$ \\ ${ }^{1}$ Student of Doctor of Business Administration-Higher Education Management at University of Bath, Bath, \\ United Kingdom \\ ${ }^{2}$ Business School faculty at Bahrain Polytechnic, Bahrain \\ Correspondence: Fahdia Khalid, Business School faculty at Bahrain Polytechnic, Bahrain. E-mail: \\ F.Khalid@bath.ac.uk
}

Received: March 21, 2018

Accepted: April 7, 2018 Online Published: December 1, 2018

doi:10.5539/hes.v9n1p40

URL: https://doi.org/10.5539/hes.v9n1p40

\begin{abstract}
Higher Education Institutions (HEIs) are undergoing financial, structural and cultural transformation. With the marketization of higher education, 'war for talent' is also gaining momentum. As bars are raised on evaluating academics' performance, the human resources and academic leadership need to rethink their approach to talent identification, development, and deployment. The staff development function needs some adaptations to sustain in this knowledge-intensive industry. In the light of literature review and professional reflection, I argue academics as 'the talent' for any higher education institution. This paper discusses talent development in higher education and advocates 'an exclusive' approach to their professional development. It unpacks the three levels of HEIs talent development needs and presents a framework to meet them. The paper also elaborates on the interventions that are favourable for the fulfilment of academics' and institution's talent development needs. It finally proposes areas for further research.
\end{abstract}

Keywords: talent, talent development, higher education, higher education institutions, talent development interventions

\section{Introduction}

Over the last few decades, the higher education industry has grown immensely, the 'war for talent' (Chambers et al., 1998) has become very relevant to the growing competition between institutions and nations; especially in recruitment for academic leadership and teaching positions. The internationalization of higher education industry and diversity and inclusion agendas has taken this 'war for talent' to a whole new level. Now, academics (subject and teaching experts) are expected to exhibit a range of new set of competencies (Potgieter et al., 2011) (Figure. 1) that were not considered relevant before. Moreover, it does not merely remain a concern of hiring talented people but also retaining, training and deploying their abilities to meet the strategic outcomes for HEIs. In the human resource and organizational management fields of studies, it is described as talent development (TD). The concept of talent development is still relatively new for the higher education (Tyagi et al., 2017) sector, nevertheless it is critical for the HEIs success as they are highly dependent on the human capital i.e., the people's knowledge, skills, and competencies (Baruch, 2017).

In this paper, I have discussed talent in the organizational settings of HEIs, and how talent development process can be applied to meet the changing expectations. Firstly, I have discussed the talent and talent development concept as a human resource development topic in higher education; I have elaborated on identifying talent, talent development, and effective talent development system. I have then discussed these concepts in the higher education context to review the need for improvising existing development functions. Finally, I have discussed TD interventions that are perceived conducive for academics' talent development. 
Ranked competencies in order of importance

\begin{tabular}{|l|}
\hline \multicolumn{1}{|c|}{ Importance to job } \\
\hline Leadership of my overall team and individual team members \\
Motivation of my overall team and individual team members \\
Performance management \\
Quality awareness and management, according to policies (equity, disability, harassment, etc) \\
Managing change and renewal \\
\hline Financial and commercial understanding \\
\hline Project management \\
Communication skills \\
\hline Effective use of IT \\
\hline Creative problem solving and decision making \\
\hline Strategic planning and formulation \\
\hline Organising and structuring my department for maximum productivity \\
\hline Strategy implementation \\
\hline Time management \\
\hline One-to-one counselling of subordinates and team members \\
\hline Day-to-day planning \\
\hline Monitoring and dissemination of information \\
\hline Emotional intelligence \\
\hline Customer care and customer service management: external \\
\hline Training and developing others \\
Delegation of tasks to my team or team members \\
\hline Customer care and customer service management: internal \\
\hline Negotiation and conflict resolution \\
\hline Handling grievance and disputes \\
\hline Managing external relationships \\
\hline Administration, reporting performance and financials, monitoring and developing reporting systems \\
\hline Managing diversity and cross-cultural issues in my department \\
\hline Risk identification and management \\
\hline Rewarding performance of my team and team members \\
\hline Planning and running meetings and effective follow-up \\
\hline Employment and HR policy awareness and management \\
\hline Dealing with issues of discipline \\
\hline Assessing training needs of my team and individual team members \\
\hline Environmental scanning and analysis \\
\hline Managing interdepartmental relationships \\
\hline Creating and giving effective presentations to groups \\
\hline Business writing \\
\hline Attracting talent \\
\hline Effective induction and orientation of new staff members \\
\hline Occupational health and safety awareness and management \\
\hline
\end{tabular}

Figure 1. (Potgieter et al., 2011) Competencies for academics

\section{Understanding Talent and Talent Development-Conceptual Framework}

\subsection{Understanding Talent}

Over the years human resource department has become a strategic partner in organizational decision making and planning. Today, as the organizations are going global and competitiveness is increasing, the need to develop and upskill employees is becoming more crucial for their success. Successful organizations always aspire for an effective training and development programme (Pfeffer, 1998). A robust system is advocated to retain, develop and deploy the organizational talent for its success and that is how a paradigm shift was brought in the learning and development function of organizations as talent development.

The management world was first introduced to the term 'talent' in the 90s when McKinsey's spoke about 'war for talent' among companies. At an individual level, "talent is something exemplary that certain people possess" (Garavan et al., 2012). It has also been addressed as capital, identity, giftedness (Dries, 2008). In an organizational context, it is described as individuals who can add value to enhance organizational performance (Tansley et al., 2007; Goffee and Jones, 2009). Redford (2005) describes it as "the collective sum of potential when employees perform at their best" (p.20). Another comprehensive definition comes from Stahl et al. (2007) that suggest that "Talent consists of those individuals who can make a difference to organizational performance, either through their immediate contribution or in the longer term by demonstrating the highest levels of potential." 
(p. 8). Moreover, managerial talent is defined as "a code for the most effective leaders and managers at all levels, who can help a company fulfill its aspirations and drive its performance. Managerial talent is some combination of a sharp strategic mind, leadership ability, emotional maturity, communications skills, and the ability to attract and inspire other talented people, entrepreneurial instincts, fundamental skills and the ability to deliver results" (Michaels et al., 2001). With above literature review it can be argued that, at a point in time, there is a specific set of competent people who can be considered as the 'talent' for an organization and Meaning thereby that defining talent is subjective and relates to the organizational strategic needs. The people or positions that are indelible for the achievement of organizational existing and future goals are called 'talent' for that organization; as organizations differ in their strategic agendas they require a separate set of competencies for the fulfillment of those needs.

The critical question is the 'know-how' of the talent for an organization and how to identify the talent by applying that know-how of talent for an organization. There are two major approaches to identifying talent in organizations that in turns changes the way organizations develop and retain that (identified) talent. Some organizations, following inclusive approach consider that every employee in the organization is a talent and of excellent value to the organization (Tansley et al., 2007) whereas some, following exclusive approach, separate a set of employees and positions and marked them of more crucial importance based on criteria that varies between organizations and industries (Gallardo-Gallardo and González-Cruz, 2013). The organizations feel more comfortable in advocating the inclusive approach (Swailes et al., 2014), employees often like it as it implies equal opportunities for everyone rather than reserving it to the people who are believed to have above average ability and capacity to succeed. Nevertheless, identifying talent has implications towards differentiation, comparison, and competition among organizations. So, it is the organization to decide what talent identification approach it wants to adopt as both approaches have merits that are subjective to individual organizational needs (Gallardo-Gallardo and González-Cruz, 2013).

\subsection{Talent Development (TD)}

Organizations want to continue to succeed, provide excellence and perform at their best, to do so, they aspire to identify, retain and deploy their talent in a most effective manner which is called talent development (Iles et al., 2010, p.127). By developing the talent of employees, organizations develop their organizational talent pool to supply the future competency needs. It can be argued that at work, organizational talent development is not possible without developing talent at the individual employee level. So, they both should be discussed in conjunction as they both support each other (Gallardo-Gallardo and González-Cruz, 2013). It is important to conceptualize the individual and organization needs in conjunction. At an individual employee level, TD is a process of learning and practicing that is catalyzed by intrapersonal and environmental factors Gagne (2000). 


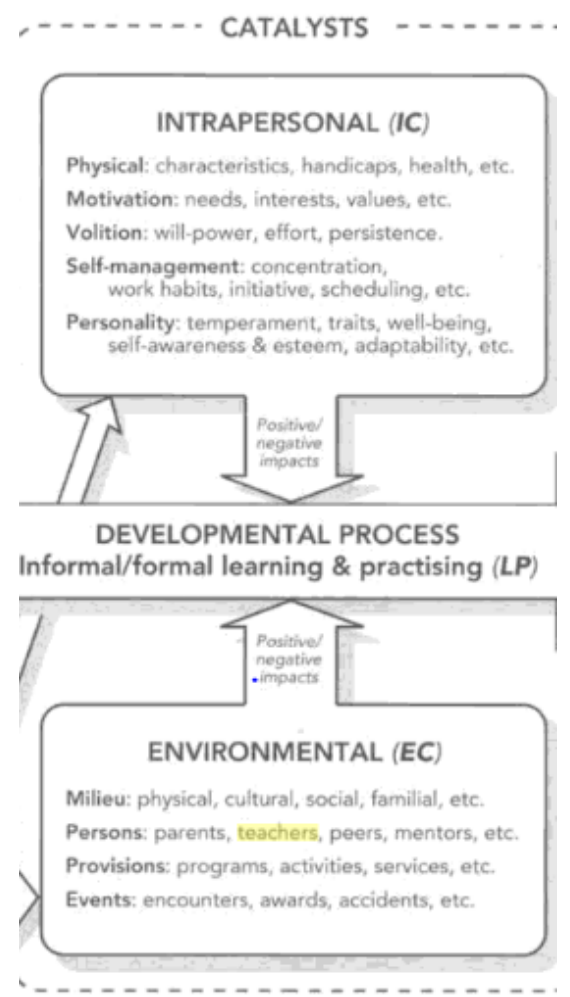

Figure 2. Catalysts for Talent Development process extracted from Gandz (2006)

These factors not only accelerate the development process but can also deteriorate or inhibit the development if not established carefully. The intrapersonal catalysts are the individual's self-awareness, self-management, and other personality and physical attributes. The environmental catalysts include the social environment, the people (including peers, bosses, friends), the events in an individual's personal or professional life (e.g. appreciation, celebration) and developmental opportunities (e.g., competency development programmes, formal learning, competitions, group learning, coaching etc.) that facilitate and speed up the talent development process. The organizations that are conscious of developing and retaining their talent, take a more systemic approach to set up the environment and learning opportunities to fit the organizational talent needs (Garavan et al., 2012). The impact of the environmental factors is significantly important as it not only affects the talent development (TD) but also affects the influence of the intrapersonal catalyst. For example, if an employee learns and acquires new skills that do not result in any benefit (extrinsic or intrinsic) for that employee, it can demotivate the employee and can affect negatively on the willingness to continue the development efforts. Gandz (2006) illustrates that link as talent development system. The TD function, Gandz (2006) suggests, is not a standalone activity and highly dependent on the successful integration of human resource management functions, represented as "meta-system" in Figure-3. TD, in an organizational setting, can be described as "the planning, selection, and implementation of development strategies for the entire talent pool to ensure that the organization has both the current and future supply of talent to meet strategic objectives" (Garavan et al., 2012). 


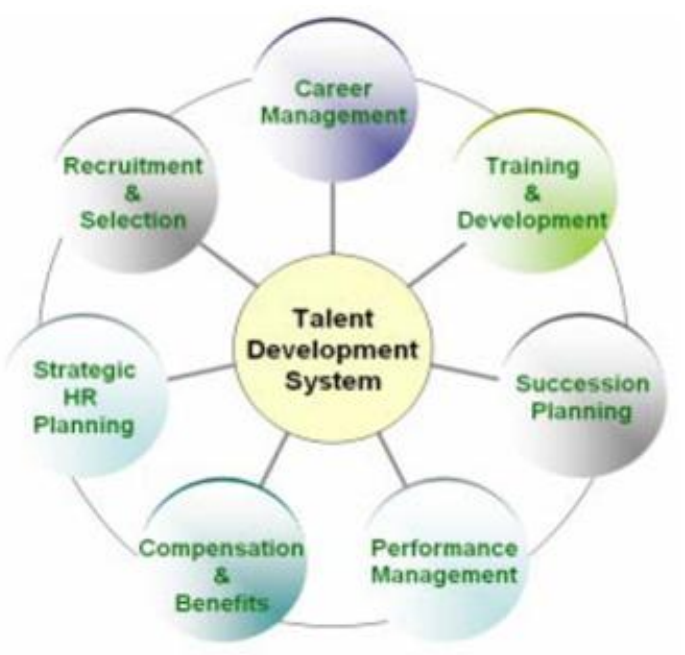

Figure 3. Gandz (2006) Talent Development System

\subsection{Conceptual Framework}

As discussed before that TD is highly dependent on the organizational and individual needs match, there cannot be one standard model that can be applied to any industry, any organization and/or to any job without strategic customization and adaptation. The TD is to be systemically structured at both individual and organizational level in full alignment with each other. Therefore, TD must also be integrated with business and other strategies of the organization so that the individuals' competency development becomes organizational talent development. Following on with the discussion so far, we can summarize the discussion as Figure-4.

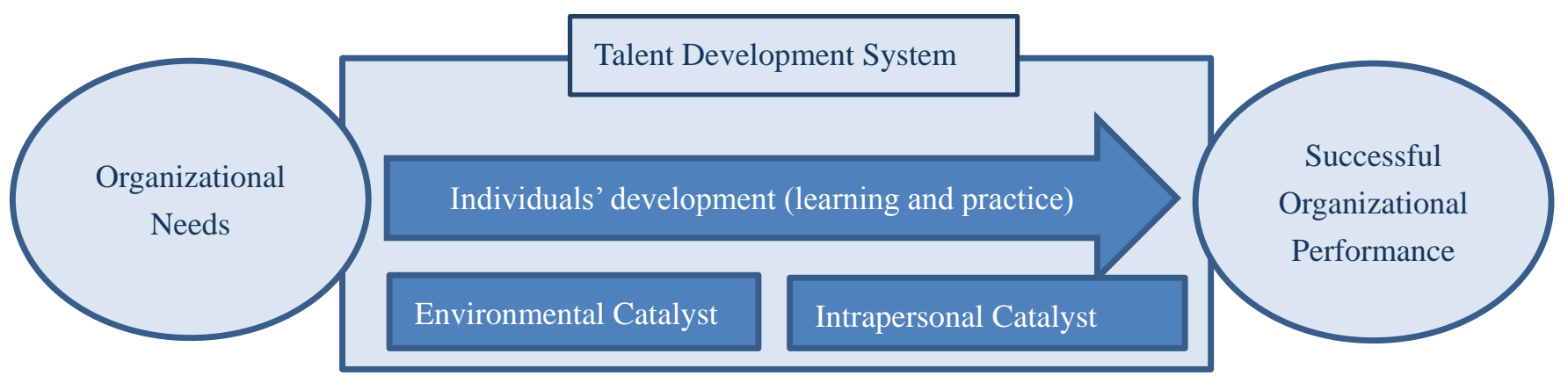

Figure 4. The integrated conceptual framework for TD from organization to individual level: Synthesizing literature

\section{Understanding Talent and Talent Development in HE}

Organizations and their employees are expected to continue to learn and develop to cope up with the dynamic industry environment. The higher education industry is no different; its environment is rapidly going global with increasing international academic staff and student populations, offshore commencement of study modules and/or exporting study programmes to various parts of the world. Such trends require professional development (Dewey \& Duff, 2009) especially in terms of enabling employees to better understand the customs, expectations and exhibit competencies to operate in the international context. The HEIs that have been conscious about talent development, have seen significant improvement in their employees' performance as well as their business sustainability. TD, in HE, like other industries, supports better human resource planning, succession planning and overall performance (Dhanabhakyam \& Kokilambal, 2014).

The HEIs are knowledge-intensive organizations, they depend upon specialist knowledge and skills to continue to meet their objectives (Stewart and Rigg, 2011) that associate their talent with positions. The academic positions are often one of the critical deficit job positions in many countries. The increasing economic migrations 
and international recruitment somewhat fill the need by brain drain from Asian countries but HEIs often struggle with finding the right people for many levels of academic leadership positions such as Head of Departments, Head of School, Deans and up to the CEOs (the title for the top position in the private sector universities). Often, the academic subject experts with a high portfolio of research are assigned on the academic leadership positions and they get overwhelmed by the robust expectations and multidimensions of the role. Although HEIs approach global recruitment companies to hunt for these positions but that is not a sustainable and risk-free, there is a sheer need to develop such talent from within the organizations so that HEIs become self-sufficient to cater to the future competency needs. The talent that is being developed within the organization and brought up in the leadership hierarchy perform arguably better on academic managerial positions as they already have a strong organizational procedural and cultural knowledge base ingrained throughout the years of experience. The TD practitioners can then identify the competency gap between the academic's existing competency level and the new job requirement to finally device customized TD interventions. In the TD literature, these needs are known as Job level and individual level needs. The job level development needs can arguably be considered the knowledge and skills that are associated with the successful performance on a job and individual level development needs are concluded by identifying the gap between individuals' existing skill/knowledge level and the job specification.

The organizational level development needs are informed by job/position and individual level needs (Boydell, 1983; Harrison, 2009). Sometimes organizational level needs are also described with specific competency and number of people who need to be developed on that competency. These organizational talent developmental needs are more generic and applicable to all employees irrespective of their position (Stewart and Rigg, 2011, p.174). Nevertheless, with changing working models for HE, the academic leadership competencies needing to be developed for effective roles, are also changing (Murphy, 1992).

The table below illustrates the link between organizational, job and individual level talent development needs in the HEIs context. It also highlights how TD approach changes from inclusive to exclusive as the needs become specific. The TD interventions are explained in the following section.

Table 1. Talent Development Needs in HEI's context: synthesizing literature

\begin{tabular}{|c|c|c|c|}
\hline $\begin{array}{l}\text { Exclusive-TD for } \\
\text { strategic talent }\end{array}$ & Needs & Position & Example \\
\hline & $\begin{array}{l}\text { Individual level- } \\
\text { Personalization of } \\
\text { TD-interventions }\end{array}$ & $\begin{array}{l}\text { Development needs } \\
\text { for the new role from } \\
\text { head of school }\end{array}$ & $\begin{array}{l}\text { Head of school to Dean } \\
\text { The HEI-leadership job level competencies } \\
\text { (Potgieter, 2011, p.95) are ought to be } \\
\text { benchmarked to develop TD-interventions } \\
\text { for everyone on the role. }\end{array}$ \\
\hline & $\begin{array}{l}\text { Job level } \\
\text { Customization of } \\
\text { TD-interventions }\end{array}$ & Academics & $\begin{array}{l}\text { Academics are under an unprecedent } \\
\text { pressure to perform on a range of academic } \\
\text { positions (Franco-Santos, et al., 2013, p.25). }\end{array}$ \\
\hline $\begin{array}{l}\text { Inclusive- } \\
\text { for all }\end{array}$ & $\begin{array}{l}\text { Organizational level } \\
\text { Generic } \\
\text { TD-interventions }\end{array}$ & Technology Skills & $\begin{array}{l}\text { Use of technology (smart boards, web } \\
\text { resources) for teaching and learning } \\
\text { activities. }\end{array}$ \\
\hline
\end{tabular}

The HEIs and academics are also required to constantly improve their knowledge and understanding about the changing expectations of all the stakeholders such as industry, government, stokes holders and students. Whenever it comes to academic talent development, quite often the focus remains on the subject-specific knowledge and research and teaching practice (Roscoe, 2002). Academics must develop new skills and increase their knowledge beyond academic research, they need to understand the competitive environment that surrounds them and their institution. For example, interpersonal skill development becomes crucially important in an international context when stakeholders are a mix of nationals from parent country [the origin place of an HEI], host country [where off-shore campus is placed] and third country [students and teachers from other countries] (Iles and Zhang, 2013). The HEIs of today are modern organizations that should provide developmental opportunities to all employees.

Higher education has talent in both academic and administrative staff. There is a need to improve human resource management functions and strategies for expected results (Wu et al., 2016). The conceptual framework presents these human resource management functions as Talent development system. A sustainable and strong talent development system (Gandz, 2006) can motivate academics intrinsically and extrinsically to avail TD 
opportunities that are provided by the institution. Such a TD system promises a progressive career, better compensation, and opportunities for growth that is based on performance and competencies development. These benefits can reach to the academic staff and leadership only through well-integrated human resource management functions for academics ( $\mathrm{Wu}, 2016)$.

Once the organizational needs and success criteria are known, talent identification strategy is agreed, and the talent development system is integrated, the next critical question is how to go about developing the academic talent i.e., what are the TD methods that are conducive to HEIs' context to develop talent for the present and future academic leadership needs. How TD-interventions can be established to provide learning opportunities that are customized to fill the individual, job and organization level competency need (Stewart and Rigg, 2011, p.174). The following section elaborates on talent development practices and interventions that are conducive in higher education settings.

\section{Talent Development Practices in HE}

The learning and development function for the academic human resource has always established separately/differently from the development function of allied or administrative staff, for the obvious reason of the difference in their job description and crucial importance. However, with the increasing competition in the HE industry and the infusion of 'war for talent', the academic human resource management and development has started to become more aggressive; though relatively very new but 'talent development' interventions are starting to emerge in the HE organizational settings as well (Tyagi et al., 2017). The talent development practices are selected strategically. HEIs often adapt a combination of methods with sufficient flexibility. Before elaborating on TD interventions, I am going to discuss the broad development categories that are formal education, job experience, and assessment and interpersonal relationships (Noe et al., 2007).

\subsection{Formal Education}

Some HEIs support their academics for formal education that includes financial or operational support to complete formal degrees, professional certifications, and other short courses. Such as, by providing study leave, sabbaticals (Else, 2015), scholarships and other formal professional development courses (Fry et al., 2008). It enables academics enhancing their subject knowledge and/or job performance. HEIs, in many parts of the world, are required to establish their own teaching and learning centers, they continuously offer a range of in-house development opportunities. These centers also organize training programmes to cater to the new developments in the field of teaching and learning such as training on blended learning, use of technology for the content delivery, student's performance management systems etc. A growing number of universities use technology and develop e-tutorials for essential yet basic skills. Generally, when it comes to developing their own academics for the university's leadership positions much attention is given on recruiting rather than developing academics for these positions. HEIs, as part of their strategic objectives, encourage academics for further studies, they also sometimes, provide funds for enrolment and research. Enhancing academic's talent with formal education has strategic importance for HEIs, as the academics' research and formal education portfolio improve it rises HEI's ranking in the league tables.

\subsection{Assessment}

Another approach to academic talent development is through assessments. The management practice of collecting performance data (from a variety of sources) and providing feedback for improvement also works well in the academic world (Franco-Santos et al., 2013). The academics' performance data is often collected from student surveys, line manager's feedback and training departments of HEIs. This information helps organizations to identify people with managerial potential or ability to take greater responsibility. These assessments information is collected as performance appraisals, 360-degree feedback, performance review, satisfaction survey, peer review etc. The feedback that is provided to academics helps them improve and enhance their teaching, working or communication style, and other performance indicators. The peer's feedback is one of the key information in this regard, as it helps organizations to identify talent with potential for promotion elevated level positions within the institution. The academics are also, in some cases, are left to learn with experience and develop themselves for the new roles. This, however, has now become an expensive choice especially for the leadership positions in the dynamics of HE industry, as explained in the TD needs section.

\subsection{Job Experience}

The third approach to development academics for managerial position or future is by giving them job assignments that are not part of their regular role, these challenges force employees to learn or enhance new skills that in turns develop them for future roles (McCall, 1998). Job-rotation and job-enlargement are two very 
common approaches to provide a wider range of experiences, the employees are asked to perform the tasks that are not necessarily an in their his/her job description (Noe et al., 2007). Academics are asked to take part in group research projects that do not necessarily linked to their subject. Academics are also asked to work as consultants to their relevant industry that provide them with more industry experience which supports their teaching practices. Academics work towards accreditations, quality assurance and other compliance reporting provide them skill development through experiences. It is important to note that such experiences are of greater value if academics consider them positive rather than negative stressors.

\subsection{Interpersonal Relationship}

The professional development that occurs when employee interacts with more experienced peers in the field and learn as part of the day to day work is learning via interpersonal (Al Ariss and Dessler, 2012). Academics, like other adult learners, learn a breadth of knowledge when they interact with more experienced people or with people who are on similar jobs, shadowing and Buddying (O'Toole and Essex, 2012) are the two common approaches to this learning method. Some HEIs make conscious effort to organize the workflow in a way to enable operational and other inter-departmental interaction such as subject coordination meetings, course, and programme review teams. Research has shown that adult learning by collaboration is more effective rather than formal lecture based (Noe et al., 2007).

\section{Talent Development Interventions for Academics}

These are the developmental methods that are available to both admin and academic staff of higher education institutions that are focused on employee development. However, the organizations keen to develop talent as strategic strength and source of future competitiveness need to introduce customized talent development interventions. The TD interventions are defined as "any event that is deliberately undertaken to support, provoke or assist learning" (Stewart and Rigg, 2011). The selection of talent development intervention is a strategic choice and depends upon many factors. These TD interventions are more exclusive and customized to fit the match between organizational expectation and individual's developmental needs. These interventions are placed in three settings of away from work, at work or through work though packaged together in a variety of ways to effective learning (Stewart and Rigg, 2011) as shown in the Table 2.

Table 2. Talent Development interventions (Stewart and Rigg, 2011)

\begin{tabular}{|c|c|c|c|c|c|c|c|c|c|c|c|}
\hline & \multicolumn{11}{|c|}{ Intervention Method } \\
\hline & 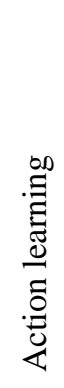 & 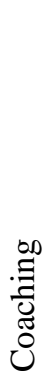 & $\begin{array}{l}000 \\
.00 \\
\frac{0}{0} \\
\sum \\
\sum\end{array}$ & 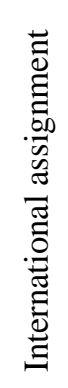 & 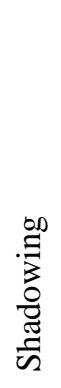 & 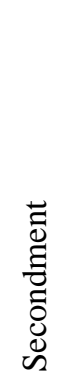 & 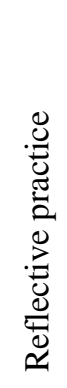 & 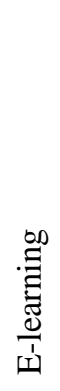 & 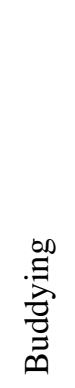 & 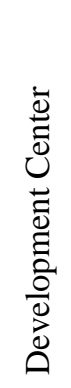 & 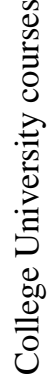 \\
\hline Away from work & & & & & & & & $\hbar$ & & 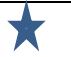 & 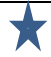 \\
\hline $\begin{array}{l}\text { At work } \\
\text { Through work }\end{array}$ & & 1 & $\hat{t}$ & 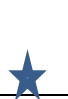 & & & $\downarrow$ & $\star$ & $\star$ & & \\
\hline
\end{tabular}

The TD interventions, 'away from work' include formal education (explained above) in development centers and/or university. The development and learning opportunities that are provided at work but do not form part of the individuals' active job are called TD 'at-work' strategies. Some of the examples are when the academic is asked to observing others perform. The interventions that develop employees while they are performing their job and through the activities that are part of their job provide development 'through work'. For example, new academics are provided mentoring to enhance their teaching practice. More examples will follow. There exist a range of possible TD interventions that are deployed as 'through work' development but the interventions that are relevant to higher education academics development are:

1) Coaching (Mabey \& Thomson, 2001; Iordanou et al., 2015)

2) Action learning (Mabey \& Thomson, 2001; Pedler et al., 2005) 
3) Mentoring (Mabey \& Thomson, 2001; Shagrir, 2017)

4) E-learning (Hou et al.,2009; Rienties et al., 2013)

These interventions are explained as below:

\subsection{Coaching}

Coaching is one of the widely used methods for employee development within and outside the academic world of higher education (Iordanou et al., 2015). In the management development field, coaching is perceived as a highly reliable TD intervention for talent maximization, leadership development and enhancing employee engagement (Stewart and Rigg, 2011). The coach who is often the line manager and coachee, the employee, work towards the achievement of certain goals that are suggested by the coach. It is often a short-term liaison for development between the learner and the coach, the learning goals are set for the learner to achieve and coach sets the process of that learning (Megginson and Clutterbuck, 2004). Though it is a 'developmental relationship' between the line manager and employee it is based on the organizational agendas. Coaching is practiced as both one-to-one (peer) and team approach. It is considered one of the core methods for employee development alongside planned study and experiences (Manpower Services Commission, 1981, p.15; Grant et al., 2010). In the academic world, this method is used to help inductees in understanding teaching practices, assessment methods, academic management, and institutional review processes. For instance, academics are given more responsible tasks towards the quality review process and they are completed under the facilitation of the coachee, Head of School, Dean, quality manager etc.

\subsection{Action Learning}

One of the recognized innovation in management development is the use of action learning that is also another commonly used method for the academics' professional development in higher education (Mabey \& Thomson, 2001). It is considered as a means of personal as well as organizational development. Following this method, learners, working in groups, are expected to act and reflect to solve problems that are aimed at developing organization and individuals (Pedler et al., 2005). The participants are not always expert on the knowledge, but they are keen to inquire and question on the context or problem. When the teaching teams meet at regular intervals to discuss and resolve issues through questioning each other on matters and viable solutions. These teaching teams are in the groups of three to eight and the learning agendas can be multi-faceted.

\subsection{Mentoring}

HE Academics prefer collaborative environment for professional development such as mentoring (Shagrir, 2017). Mentoring not only help academics on new responsibilities and to better adjust in the environment but also empower experienced academics. It is more related to the development of an individual rather than help to master a specific task. The mentor and mentee develop a long-term relationship where the learning goals and process is determined by the mentee (Megginson and Clutterbuck, 2004). It is about enabling rather than facilitating mentee to know more about him/her self. Apart from benefits to the mentee, mentoring increases career and job satisfaction and commitment to an organization that in turn increases development and retention of talent (Wanberg et al., 2003). Mentoring also benefits the organization in the form of transfer of organizational procedural knowledge (Stewart and Rigg, 2011) from senior to junior employees that will also improve the organizational culture for learning.

\subsection{E-learning}

Learning via the application of information and communication technologies (Garrison, 2011) is E-learning. It is the TD intervention where information and communication technologies are used to provide easy, cost-effective and flexible access to information. E-learning has become a key structural element in designing formal TD programmes and informal learning by networking with distant expert peers (Hou et al., 2009). E-learning not only helps academics improve their subject knowledge, teaching practice and research skill but also facilitates learning on management and leadership techniques via various online platforms. Such as webinars, Skype-tutorials, e-workshops and networking and blogging tools that allow knowledge sharing among the people of practice. E-learning allows independence from time and face-to-face interaction. It provides academics a terrific opportunity to learn and collaborate with people of research and practice in similar fields across the globe. With the development in technology (mobile) m-learning and (virtual reality) v-learning tools, critical experiential learning has become possible in simulated risk-free environments. E-learning has penetrated so well and so much into the training and development methods that it is now impossible to separate e-learning from other forms of development and use of technology has become our second nature. Other simple examples are how-to guides, induction videos, virtual meetings, a virtual tour of a new vicinity etc. The e-learning tools are 
also used in employee assessment and evaluation of developed competencies and provide follow up opportunities. It is important to mention that E-learning represents technology as a facilitator for learning rather than a benchmark of successful learning and talent development.

\section{Understanding TD success in HEIs}

Ever since the notion of markets, strategy and competitiveness has become a part of common HE management language, HEIs' success is being indicated with a range of factors that would not matter half a century ago such as financial sustainability, accreditations, quantifying scholarly output by academics, diversity in student and staff population and customer satisfaction perspectives and institution's place in the ranking etc. These indicators, directly or indirectly, are linked to the knowledge, skills, and competencies of academics and academic leadership. These people, with hard to duplicate competencies can become a reason of competitiveness and success. Such as by only recruiting academics with Ph.D. qualification raises HEI's ranking. It can be argued that by developing leadership talent of academic staff, HEIs can sustain and continue their competitive strategy and organizational culture of practice, year after year. However, when there is a question on the value or effectiveness of TD-intervention in enhancing academics competencies, providing talent pool and performance; the success is evaluated on criteria. Anderson (2007) describes four main approaches to judge the effectiveness of TD interventions that are efficiency measure, internal performance indicators, and external benchmarks, Return on Investment, Return on Expectations. The efficiency measure is based upon quantifiable indicators, for HEIs it would include numbers and ratios like a number of development hours per employee, how many competency needs are successfully fulfilled and in what time-frame, the cost of academics' time for TD activities. The second assessment method is internal performance indicators and external benchmarks which evaluates the impact of TD interventions against the key performance indicators of employees that are aligned to organization's performance against strategic goals; for HEIs the examples could be accreditations, the rise in league tables, funding inflow. The third method is the Return on Investment measure which is also about financial gains to the organization after the implementation of a TD-intervention. In the academic world, the payback time of TD is relatively long and hard to measure for a brief time-frame. The fourth assessment criterion is Return on Expectations, it can be considered a true measure of the value of the TD interventions. It is a qualitative measure that considers the actual learning. Such as, if the behavioral indicators of performance indicated changed results, has the TD-intervention facilitated succession planning for the future academic leadership positions as expected etc.

\section{Conclusion and Further Research}

Over the last half a century, 'managerialism' has penetrated the higher education systems. The notion of markets, strategy and competitiveness have become a part of common HE management language and its success is been indicated with a wider range of factors that would not matter half a century ago such as. To stay competitive, in such a volatile environment, TD can be considered a significant adaptation to academic staff development function. The paper advocates the following:

1) Academics can arguably be considered the talent for HEIs not only because of their competencies and expertise (subject knowledge, institutional tacit knowledge, teaching and research experience) in the field of their subject but also for the fact that academics performance (in both short and long-term) can make a difference to HEIs overall institutional performance on various scales such as, ranking, research output, stakeholders' expectation etc. It does not mean that non-academic HEIs' staff are not talented but in the time of internationalization academics are the strategic talent that HEIs must develop to sustain and improve their culture, strategy and to continue to stay competitive in their fields of studies.

2) The TD needs cannot be figured out as a standalone list of competencies. The HEIs need to undertake a detailed analysis of organizational, job and individual level needs in relational to critical jobs' key performance indicators that in turn can affect institutional success in time and context.

3) The HEIs can only get the benefit of TD interventions if they are integrated with human resource function. For example, academics' improved performance should be acknowledged and awarded with better career growth opportunities and/or compensation. Otherwise, it can affect negatively on the employee's development by impacting intrapersonal and environmental catalysts as discussed above.

4) TD opportunities are to be provided to all academics inclusively, however, some TD interventions need to be customized and personalized exclusively, to match employee-job competency gap. Such as talent development interventions to enhance academics on their new leadership positions. Generally, academics prefer collaborative learning environment but, the exclusive TD interventions are to be explored on a case-by-case basis to best fit the three levels of needs. 
In this paper, I have discussed academics as HEI's talent and their development from people and position perspectives. I have also presented TD interventions that are conducive for progressing academics into further leadership roles. Based on existing literature review, I have tried to present a framework that can help TD and HR practitioners to establish an integrated system of Talent development that can bridge the gap between human resource management functions and existing academics professional development function. Conceptualizing talent and talent development are relatively new in higher education settings that give us opportunities for further research. Such as, towards developing customized talent development interventions for academics in teaching and other degree programme management functions. Moreover, further exploration can be done on the stakeholders' perception and expectations on talent development and how far they will go to integrate talent development system into the overall institutional management system.

\section{References}

Al Ariss, A., \& Dessler, G. (2012). Human Resource Management (Arab World ed.).

Baruch, Y. (2017). Managing academic careers to win the War for talent. OECD. Retrieved from http://www.oecd.org/edu/imhe/39210757.pdf [Accessed 11 Sep. 2017].

Boydell, T. H. (1983). A Guide to the Identification of Training Needs. London: British Association for Commercial and Industrial Education.

Chambers, E. G., Foulon, M., Handfield-Jones, H., Hankin, S. M., \& Michaels, E. G. (1998). The war for talent. McKinsey Quarterly, 44-57.

Dewey, P., \& Duff, S. (2009). Reason before passion: Faculty views on internationalization in higher education. Higher education, 58(4), 491-504. https://doi.org/10.1007/s10734-009-9207-z

Dhanabhakyam, M., \& Kokilambal, K. (2014). A study on existing talent management practice and its benefits across industries. IMPACT: International Journal of Research in Business Management, 2(7), 23-36.

Dries, N. (2013). The psychology of talent management: A review and research agenda. Human Resource Management Review, 23(4), 272-285. https://doi.org/10.1016/j.hrmr.2013.05.001

Else, H. (2015). Sabbaticals: no longer so open-ended or available?. [online] Times Higher Education (THE). Retrieved from https://www.timeshighereducation.com/features/sabbaticals-no-longer-so-open-ended-or-av ailable/2019616.article

Franco-Santos, M., Rivera, P., \& Bourne, M. (2013). Performance Management in UK Higher Education Institutions: The Need for a Hybrid Approach: Summary Report. Leadership Foundation for Higher Education.

Fry, H., Ketteridge, S., \& Marshall, S. (2008). A handbook for teaching and learning in higher education: Enhancing academic practice. Routledge.

Gandz, J. (2006). Talent development: the architecture of a talent pipeline that works. Ivey Business Journal, $70(3), 1-4$

Gagne, F. (2000). Understanding the complex choreography of talent development through DMGT-based analysis. International handbook of giftedness and talent, 2, 67-79. https://doi.org/10.1016/B978-008043796-5/50005-X

Gallardo-Gallardo, E., Dries, N., \& González-Cruz, T. F. (2013). What is the meaning of 'talent'in the world of work?. Human Resource Management Review, 23(4), 290-300. https://doi.org/10.1016/j.hrmr.2013.05.002

Garavan, T., Carbery, R., \& Rock, A. (2012). Mapping talent development: definition, scope and architecture. European Journal of Training and Development, 36(1), 5-24. https://doi.org/10.1108/03090591211192601

Garrison, D. R. (2011). E-learning in the 21 st century: A framework for research and practice. Taylor \& Francis. https://doi.org/10.4324/9780203838761

Grant, A. M., Passmore, J., Cavanagh, M. J., \& Parker, H. M. (2010). 4 The State of Play in Coaching Today: A Comprehensive Review of the Field. International review of industrial and organizational psychology, 25(1), 125-167. https://doi.org/10.1002/9780470661628.ch4

Goffee, R., \& Jones, G. (2009). Clever: Leading your smartest, most creative people. Harvard Business Press.

Harrison, R. (2009). Learning and Development. $5^{\text {th }}$ ed. London: CIPD.

Hou, H. T., Chang, K. E., \& Sung, Y. T. (2009). Using blogs as a professional development tool for teachers: Analysis of interaction behavioral patterns. Interactive Learning Environments, 17(4), 325-340. 
https://doi.org/10.1080/10494820903195215

Iles, P., Preece, D., \& Chuai, X. (2010). Talent management as a management fashion in HRD: Towards a research agenda. Human Resource Development International, 13(2), 125-145. https://doi.org/10.1080/13678861003703666

Iles, P., \& Zhang, C. L. (2013). International human resource management: A cross-cultural and comparative approach. Kogan Page Publishers.

Roscoe, J. (2002). Continuing professional development in higher education. Human Resource Development International, 5(1), 3-9. https://doi.org/10.1080/13678860110076006

Iordanou, I., Leach, A., \& Barnes, V. (2015). Coaching in Higher Education. Coaching in Professional Contexts. London: Sage Publishing, 145-58.

Manpower Services Commission, (1981). A new training initiative: An agenda for action. MSC.

Mabey, C., \& Thomson, A. (2001). The learning manager: a survey of management attitudes to training and development at the millenium, Institute of Management.

Megginson, D., \& Clutterbuck, D. (2004). Techniques for Coaching and Mentoring. Routledge. https://doi.org/10.4324/9780080470580

McCall, M. W. (1998). High flyers. Developing the next generation of leaders. Boston.

Michaels, E., Handfield-Jones, H., \& Axelrod, B. (2001). The War for Talent: Harvard Business School Press. MA., USA.

Murphy, J. (1992). The landscape of leadership preparation: Reframing the education of school administrators. Corwin Press, Inc. (a Sage Publications Co.), 2455 Teller Road, Newbury Park, CA 91320.

Noe, R. A., Hollenbeck, J. R., Gerhart, B., \& Wright, P. M. (2007). Fundamentals of human resource management. Boston, MA: McGraw-Hill/Irwin.

O'Toole, S., \& Essex, B. (2012). The Adult Learner May Really Be a Neglected Species. Australian Journal of Adult Learning, 52(1), 183-191.

Pedler, M., Burgoyne, J., \& Brook, C. (2005). What has action learning learned to become?. Action Learning: Research and Practice, 2(1), 49-68. https://doi.org/10.1080/14767330500041251

Pfeffer, J. (1998). The human equation: building profits by putting people first Cambridge, MA: Harvard Business School Press.

Potgieter, I., Coetzee, M., \& Basson, J. (2011). Management competencies for the development of heads of department in the higher education context: a literature overview. South African Journal of Labour Relations, 35(1), 81-103.

Redford, K. (2005). Shedding light on talent tactics. Personnel Today, 22.

Rienties, B., Brouwer, N., \& Lygo-Baker, S. (2013). The effects of online professional development on higher education teachers' beliefs and intentions towards learning facilitation and technology. Teaching and teacher education, 29, 122-131. https://doi.org/10.1016/j.tate.2012.09.002

Shagrir, L. (2017). Collaborating with colleagues for the sake of academic and professional development in higher education. International Journal for Academic Development, 1-12. https://doi.org/10.1080/1360144X.2017.1359180

Spendlove, M. (2007). Competencies for effective leadership in higher education. International Journal of Educational Management, 21(5), 407-417. https://doi.org/10.1108/09513540710760183

Stahl, G. K., Björkman, I., Farndale, E., Morris, S. S., Pauwels, J., ... Stiles, P. (2007). Global talent management: How leading multinationals build and sustain their talent pipe line. INSEAD Faculty and Research Working Papers, 2007/24/O8.

Stewart, J., \& Rigg, C. (2011). Learning and talent development. Kogan Page Publishers.

Swailes, S., Downs, Y., \& Orr, K. (2014). Conceptualising inclusive talent management: potential, possibilities and practicalities. Human Resource Development International, 17(5), 529-544. https://doi.org/10.1080/13678868.2014.954188

Tansley, C., Turner, P., Foster, C., Harris, L., Stewart, J., Sempik, A., \& Williams, H. (2007). Talent: Strategy, management, measurement. Nottingham Trent University: CIPD. 
Tyagi, S., Singh, D., \& Aggarwal, T. (2017). TALENT MANAGEMNT IN EDUCATION SECTOR. International Journal on Cybernetics \& Informatics, 6(1/2), 47. Retrieved from http://aircconline.com/ijci/V6N2/6217ijci06.pdf

Wanberg, C. R., Welsh, E. T., \& Hezlett, S. A. (2003). Mentoring research: A review and dynamic process model. In Research in personnel and human resources management (pp. 39-124). Emerald Group Publishing Limited. https://doi.org/10.1016/S0742-7301(03)22002-8

Wu, M. C., Nurhadi, D., \& Zahro, S. (2016). Integrating the talent management program as a new concept to develop a sustainable human resource at higher educational institutions. International Journal of Organizational Innovation, 8(4), 146.

\section{Copyrights}

Copyright for this article is retained by the author(s), with first publication rights granted to the journal.

This is an open-access article distributed under the terms and conditions of the Creative Commons Attribution license (http://creativecommons.org/licenses/by/4.0/). 